\title{
Religiosity and Life Satisfaction in Indonesia: Evidence from a Community Survey
}

\author{
Vera Nur Choirina \\ Yogyakarta State University \\ Vera0129pasca.2019@student.uny.ac.id
}

\author{
Yulia Ayriza \\ Yogyakarta State University \\ Yulia_ayriza@uny.ac.id
}

\author{
Yoga Setyo Wibowo \\ Lembaga Survei KedaiKOPI \\ yoga.wibowo@kedaikopi.co
}

\begin{abstract}
There is a growing interest in the relationship between religiosity and subjective well-being in the literature. However, little evidence exists from Indonesia with a national scope. The aim of this study was to contribute to the literature by investigating the association between self-perceptions of religiosity and life satisfaction using nationally representative data from the Indonesia Family and Life Survey. Linear regression was used for data analysis with a sample of 27,150 individuals aged between 18 and 90 . The main findings showed that those who were religious were more satisfied with their life than their counterparts, even after controlling for a set of confounding variables. It seems that religiosity provides people with well-being benefits which might lead to good life.
\end{abstract}

Keywords: Religiosity, life satisfaction, Indonesia

Received 18 January 202I/Accepted 7 March 202I @Author all rights reserved

\section{Introduction}

Over the past decades, there has been a great interest in subjective well-being in psychology and philosophy, and recently across many disciplines. This interdisciplinary research employs subjective well-being as a proxy of quality of life (Lim \& Putnam, 2010). Subjective well-being is usually measured through and used interchangeably with happiness and life satisfaction in the literature. The former concerns the affective component of subjective well-being while the latter concerns the cognitive component of it, and both are based on the principle of hedonism (Ryan \& Deci, 200I). Life satisfaction, which is the subjective cognitive conceptualization of one's life, has been found to yield better understanding of people's well-being (Diener \& Biswas-Diener, 2008).

There is recognition of the importance of religiosity for subjective well-being in the literature. Many studies reported a positive association of religiosity with happiness, life satisfaction and overall well-being (Campante \& Yanagizawa-Drott, 20I5; Elliott \& Hayward, 
2009; Hayo, 2007). Another study found with a sample of Kuwait undergraduates found that religiosity contributed to $15 \%$ of the variance in happiness (Abdel-Khalek, 2006). Others have argued that religiosity was related to life satisfaction under certain circumstances. For example, Okulicz-Kozaryn (2010) treated religiosity as an attribute of both individuals and societies to investigate the association between religiosity and life satisfaction in no less than seventy-nine nations. The authors found that religiosity was context dependent, indicating that religious individuals were more satisfied with their life in religious countries. A similar trend was found by Eichhorn (2012) in 43 European and American countries using data from the World Values Survey. They reported that individual religiosity was highly associated with life satisfaction only in religious societies. While many studies found a positive relationship, Mochon, Norton, and Ariely (20II) revealed a negative association between happiness and moderate religious attendance, and those with weak beliefs had decreased levels of happiness than those without any faith.

The association of life satisfaction and religiosity is interesting given that the number of people reporting that they are religious is considerable. One study reported that $85 \%$ of the world population was religious or at least were involved in some forms of religious beliefs (Zuckerman, 2005) and only 15\% stated that they were not religious, atheists, or agnostics (Zuckerman, 2005). A report of the Gallup showed that $94 \%$ of people in the Unites States reported that they believed in God, $82 \%$ claimed that religion was important to them (Gallup, 2009). In Indonesia, a study used a community survey and reported that more than 72\% reported that they were religious (Nizeyumukiza, Cilik Pierewan, Ndayambaje, \& Ayriza, 2020). Given this prevalence of perceived religiosity in people's life world widely, it is assumable that it plays an important role in how people conceptualize their life. Thus, it is of great importance to study the links between the two variables.

Although many studies have been conducted on the relationship between religiosity and life satisfaction globally (Campante \& Yanagizawa-Drott, 2015; Elliott \& Hayward, 2009; Hayo, 2007), few have been conducted in Indonesia using nationally representative data (Ramadhani, 2019; Wahidin, 2017). The purpose of the present study was to contribute to the literature investigate the association between self-perceptions of religiosity and life satisfaction in Indonesia using a community survey. 


\section{Methods}

Data and sample

The current study used data from the fifth wave of the Indonesia Family and Life Survey conducted in late 2014 and early 20I5. IFLS is an ongoing sociodemographic and health survey conducted by Rand Corporation and the survey METER (Yogyakarta, Indonesia) since 1993. The survey employed multistage and stratified sampling to collect data at the individual level, household level and at the community level (Strauss, Witoelar, \& Sikoki, 2016). The fifth wave collected information on 16,204 households and 50, I48 individuals aged 15 and older. Respondents were given an informant consent and were informed about the background, goal, risks, and benefits of the survey (Strauss et al., 2016). After cleaning missing data for life satisfaction, a sample of 27,150 aged between 18 and 90 was yielded.

\section{Variables}

Life satisfaction served as the dependent variable in this study. To measure life satisfaction, the survey asked respondents to think about their life as whole and rate how they are satisfied with it. Possible answers ranged between I not at all satisfied and 5 completely satisfied. The descriptive statistics of the life satisfaction variable are found in Table I.

Religiosity served as the dependent variable. The survey asked respondents to think about how religious they are and give a rate. The answers included very religious, somewhat religious, rather religious and not religious. In the purpose of this analysis, the authors wanted to differentiate between religious individuals and non-religious individuals. Therefore, two dummies were made. A dummy one was given to religious individuals (very religious and somewhat religious) and a dummy code 0 was given to non-religious individuals (rather religious and not religious).

Many factors could possibly confound the relationship between religiosity and life satisfaction, including gender, age, education, marital status, smoking behaviors, unemployment status, social trust, personality trait, and self-rated health. Therefore, these variables were entered in the analysis. A dummy code I was given to male respondents and 0 to females. For the education completed variable, a dummy code one was given to elementary school, 2 to junior high school, 3 to senior high school, and 4 to high education. 
For marital status, a dummy code I was given to married individuals and 0 to not married (single, widowed, and divorced). For the smoking behavior variable, respondents were asked by the survey whether they smoked cigarettes or cigar. Those who responded yes were given a dummy code $\mathrm{I}$ and 0 otherwise. Concerning the unemployment variable, those who were working were given a dummy code 0 and those in search for jobs or housekeepers were given a dummy code I. For the social trust variable, the survey asked respondents to imagine if they lost a wallet with Rp. 200.000 and an identity card in it and to think how was it likely to be returned if it was found by someone living close to them. The answers ranged between I very unlikely to 4 very likely. Extroversion trait was used to account for personality and was measured using the short version of the big five inventory (Rammstedt \& John, 2007). For the self-rated health variable, a dummy code I was given to respondents who reported that they were very healthy and somewhat healthy and a dummy code 0 was given to those who reported being somewhat unhealthy and very unhealthy.

The data were managed and analyzed using the R statistical software (Fox \& Leanage, 2016). Two models were computed in this analysis. The model one included religiosity as a single predictor to check the association between religiosity and life satisfaction. Model 2 included to model one a set of confounding variables to check whether this association hold true after controlling for these confounders.

\section{Results}

The descriptive statistics of the sample are summarized in Table I.Morethan 70\% reported to be religious while slightly less than $30 \%$ reported that they were not religious. Around $53 \%$ were males and $47 \%$ were females. Thirty-seven percent had completed elementary school, 23.4\% junior school, 34 senior school, and 5.6\% high education. More than $78 \%$ were married, and over $95 \%$ were smokers. More than $78 \%$ reported that they were healthy. 
Table I

Descriptive Statistics of the Sample

\begin{tabular}{|c|c|c|c|c|c|c|c|}
\hline Variable & Min & Max & Mean & SD & $\%$ & Mean (SD) LS & $\mathrm{n}$ \\
\hline \multicolumn{8}{|l|}{ Religiosity } \\
\hline Religious & & & & & 72.8 & $3.34(0.77)$ & 16,456 \\
\hline Non-religious & & & & & 27.2 & $3.16(0.79)$ & 6,142 \\
\hline \multicolumn{8}{|l|}{ Gender } \\
\hline Female & & & & & 53 & $3.37(0.78)$ & 12,739 \\
\hline Male & & & & & 47 & $3.26(0.7 I)$ & $|4,4| \mid$ \\
\hline \multicolumn{8}{|l|}{ Education } \\
\hline Elementary school & & & & & 37 & $3.23(0.84)$ & 8,048 \\
\hline Junior high school & & & & & 23.4 & $3.32(0.78)$ & 5,089 \\
\hline Senior high school & & & & & 34 & $3.33(0.77)$ & 7,528 \\
\hline High education & & & & & 5.6 & $3.43(0.70)$ & 1,093 \\
\hline \multicolumn{8}{|l|}{ Marital status } \\
\hline Married & & & & & 78.2 & $3.32(0.79)$ & 21,239 \\
\hline Unmarried & & & & & 21.8 & $3.30(0.80)$ & 5,911 \\
\hline \multicolumn{8}{|l|}{ Smoking behaviors } \\
\hline Smoking & & & & & 95.7 & $3.23(0.83)$ & 9,709 \\
\hline Non-smoking & & & & & 4.3 & $3.13(0.77)$ & 435 \\
\hline \multicolumn{8}{|l|}{ Self-Rated Health } \\
\hline Healthy & & & & & 78.5 & $3.37(0.77)$ & 21,275 \\
\hline Unhealthy & & & & & 21.5 & $3.12(0.84)$ & 5,766 \\
\hline Life Satisfaction & I & 5 & 3.32 & 0.79 & & & 27,150 \\
\hline Age & 18 & 90 & 38.64 & 13.99 & & & 27,150 \\
\hline Extroversion & 2 & 10 & 7.18 & 1.33 & & & 27,030 \\
\hline Social trust & $\mathrm{I}$ & 4 & 2.88 & 1.07 & & & 27,150 \\
\hline
\end{tabular}

Mean (SD) LS: mean and standard deviation of life satisfaction scores per categories.

The mean score was $3.32(S D=0.79$, range $=1-5)$ for life satisfaction, $38.6(S D=13.99$, range $=18=90)$ for age, $7.18(S D=1.33$, range $=2-10)$ for extroversion, and $2.88(S D=$ I.07, range $=1-4$ ) for social trust.

The results of the multivariate analysis are showed in Table 2 . The model I indicated a significant relationship between religiosity and life satisfaction $(\beta=0.17, p<0.00 \mathrm{I})$. The model two indicated that even after including confounding variables, the positive relationship between religiosity and life satisfaction remained significant $(\beta=0.14, p<0.00 \mathrm{I})$. 
Table 3

Multivariate Regression Model Predicting life satisfaction

\begin{tabular}{|c|c|c|c|c|}
\hline \multirow{2}{*}{ Variable } & \multicolumn{2}{|c|}{ Model I } & \multicolumn{2}{|c|}{ Model 2} \\
\hline & Coef. & SE & Coef. & SE \\
\hline Intercept & $3.16^{* * *}$ & 0.00 & $2.76 * * *$ & 0.09 \\
\hline \multicolumn{5}{|l|}{ Religiosity (ref. non-religious } \\
\hline Religious & $0.17^{* * *}$ & 0.01 & $0.14 * * *$ & 0.02 \\
\hline \multicolumn{5}{|l|}{ Gender (ref. Female) } \\
\hline Male & & & -0.03 & 0.04 \\
\hline Age & & & $0.00 * * *$ & 0.00 \\
\hline \multicolumn{5}{|l|}{ Education (ref. elementary } \\
\hline Junior HS & & & 0.02 & 0.02 \\
\hline Senior HS & & & $0.02 * *$ & 0.06 \\
\hline High Education & & & $0.11 *$ & 0.05 \\
\hline \multicolumn{5}{|l|}{ Marital (ref. unmarried) } \\
\hline Married & & & -0.00 & 0.02 \\
\hline \multicolumn{5}{|l|}{ Smoking (ref. non-smoking) } \\
\hline Smoking & & & 0.04 & 0.05 \\
\hline Social trust & & & $0.03 * * *$ & 0.00 \\
\hline Extraversion & & & $0.02 * * *$ & 0.00 \\
\hline \multicolumn{5}{|l|}{ SRH (ref. unhealthy) } \\
\hline Healthy & & & $0.22 * * *$ & 0.02 \\
\hline Adjusted R2 & 0.009 & & 0.03 & \\
\hline
\end{tabular}

$* p<0.05, * * p<0.01, * * * p<0.00$ I; SE: Standard Errors; SRH: self-rated health

Some of the control variables exhibited significant associations with life satisfaction. Those who completed senior high school and high education were more satisfied with life than those who completed only elementary $\operatorname{school}(\beta=0.02, \quad p<0.01$ and $\beta=0.11, \quad p<$ 0.05 respectively). Social trust was positively associated with life satisfaction $(\beta=0.03, p<$ $0.00 \mathrm{I})$. extroversion and self-rated health were positively associated with life satisfaction $(\beta=0.02, p<0.001$ and $\beta=0.22, p<0.001$ respectively $)$.

\section{Discussion}

There is an increasing scholarship on the association between religiosity and subjective wellbeing globally, with little evidence from Indonesia however. This study was aimed to 
contribute to the literature by investigating the association between self-perceptions of religiosity and self-reported life satisfaction using nationally representative data. The main results showed that religious individuals were more satisfied with their life than their counterparts. This trend persisted even after controlling confounding variables.

The findings of this study corroborate those of previous studies. Dilmaghani (2017) used the Canadian Ethnic Diversity Survey to investigate how the religiosity was associated with subjective well-being. They found that religious attendance was positively correlated with subjective well-being. Using a Muslim sample, Abdel-khalek (2019) reported a positive association between religiosity and health and subjective well-being. Ferriss (2002) analyzed data from an American social survey and reported a positive link of church attendance and subjective well-being measures. A similar trend was found in Eastern Europe where a study reported that regular church attenders had increased levels of life satisfaction (Hayo, 2007). Greene and Yoon (2004) used data from the Eurobarometer to investigate the links between religiosity and life satisfaction. They found that frequent religious attendance was positively associated with people's life satisfaction. World widely, the positive association seems to hold true as well. Elliott and Hayward (2009) used the $4^{\text {th }}$ wave of the world values survey that included not less than 65 countries using multilevel models to address the relationship between religiosity and life satisfaction. Their study revealed a positive association worldwide although certain government regulations affected the association. Causal relationships have been reported as well. Campante \& Yanagizawa-Drott (20I5) used the variations of Ramadhan months as an instrument and established causal positive effects of religious practice on subjective well-being, although the impact was negative for economic performance.

The reason why religiosity matters for subjective well-being has been proposed in the literature. One of the reasons is that religion provides people with personal networks and support (Lim \& Putnam, 2010). According to this view, religion increases life satisfaction by providing a ground for social interaction which increases friendships and social ties. Religious attenders share similar beliefs are more likely to provide comfort and support for one another. Another reason is that religion members make ties that allow them to have a sense of belongingness which improves physical and mental health (Krause \& Wulff, 2005).

Some of the other control variables showed a significant association with life satisfaction as well. Education was positively associated with life satisfaction in this study. Those who 
completed senior high school and high education were more satisfied with life than those who completed only primary education. This is in line with previous studies which found happiness to be more associated with having completed senior high school and high education than having completed elementary school in Indonesia (Nizeyumukiza et al., 2020). Social trust was significantly associated with life satisfaction which corroborates previous findings from Indonesia (Nizeyumukiza et al., 2020; Pierewan \& Veenhoven, 20I8). Extroversion personality trait and self-rated health were consistently associated with wellbeing which is in line with prior studies (Lucas, 2018; Ndayambaje, Pierewan, Nizeyumukiza, Nkundimana, \& Ayriza, 2020; Ngamaba, Panagioti, \& Armitage, 2017; Nizeyumukiza, Pierewan, Ndayambaje, \& Ayriza, 202I).

The study is not without limitations however. First, although it used data of national scope, no cautions can be made because of the cross-sectional nature of the data. Secondly, the measures used were self-perception reports of religiosity and life satisfaction. The strength of the study resides in the national scope of the data. Moreover, the multivariate analysis used allowed to control for a set of confounding variables.

\section{Conclusion}

Using data from a community survey, this study revealed a positive relationship between religiosity and life satisfaction. It seems that people derive benefits from being affiliated to a religion and the associated beliefs which lead them to making meaning of life and consequently get satisfied with it. Okulicz-Kozaryn (2010) argued that religion satisfies the "need to belong" which is one of the fundamental human needs in the pursuit of happiness.

\section{Acknowledgement}

The study used cross-sectional data from the fifth wave of the Indonesia Family Survey conducted by RAND Corporation (https://www.rand.org/well-being/social-and-behavioralpolicy/data/FLS/IFLS/ifls5.html). The authors are therefore grateful to RAND Corporation who provided free access to the data and to the Indonesian respondents who responded the survey. 


\section{References}

Abdel-khalek, A. M. (2019). Religiosity and subjective well-being in the Arab context: addendum and extrapolation. Mental Health, Religion \& Culture ISSN:, 22(8), 860-869. https://doi.org/I0.1080//3674676.2019.1687/35

Abdel-Khalek, A. M. (2006). Happiness, health, and religiosity: Significant relations. Mental Health, Religion and Culture, 9(I), 85-97. https://doi.org/I 0. I 080/I3694670500040625

Campante, F., \& Yanagizawa-Drott, D. (2015). Does religion affect economic growth and happiness? Evidence from Ramadan. Quarterly Journal of Economics, 130(2), 6I5-658. https://doi.org//0.1093/qje/qjv002

Diener, E., \& Biswas-Diener, R. (2008). Happiness: Unlocking the mysteries of psychological wealth. Malden, Oxford and Victoria: Blackwell.

Dilmaghani, M. (2017). Religiosity and subjective wellbeing in Canada. Journal of Happiness Studies. https://doi.org/I0.1007/s 10902-016-9837-7

Eichhorn, J. (2012). Happiness for believers? Contextualizing the effects of religiosity on lifesatisfaction. European Sociological Review, 28(5), 583-593. https://doi.org//0.1093/esr/jcr027

Elliott, M., \& Hayward, R. D. (2009). Religion and life satisfaction worldwide: The role of government regulation. Sociology of Religion: A Quarterly Review, 70(3), 285-310. https://doi.org// 0.1093/socrel/srp028

Ferriss, A. (2002). Religion and the quality of life. Journal of Happiness Studies, 3(3), 199-2I 5. https://doi.org/I0.1023/A:1020684404438

Fox, J., \& Leanage, A. (2016). R and the Journal of Statistical Software. Journal of Statistical Software, 73(2). https://doi.org/10.18637/jss.v073.i02

Gallup. (2009). Religion. Retrieved from http://www.gallup.com/poll// 690/Religion.aspx

Greene, K. V., \& Yoon, B. J. (2004). Religiosity, economics and life satisfaction. Review of Social Economy, 62(2), 245-26I. https://doi.org/I0.1080/003467604I000I684460

Hayo, B. (2007). Happiness in transition: An empirical study on Eastern Europe. Economic Systems, 3I(2), 204-22I. https://doi.org/I0.10I6/j.ecosys.2006.08.003

Krause, N., \& Wulff, K. M. (2005). Research: "Church-based social ties, a sense of belonging in a congregation, and physical health status." International Journal of Phytoremediation, 2I(I), 73-93. https://doi.org/I0.1207/s I5327582ijpr I50I_6

Lim, C., \& Putnam, R. D. (2010). Religion, social networks, and life satisfaction. American Sociological Review, 75(6), 9|4-933. https://doi.org/I0.II77/0003 I224I0386686

Lucas, R. E. (2018). Exploring the Associations Between Personality and Subjective WellBeing. In Ed Diener, S. Oishi, \& L. Tay (Eds.), Handbook of well-being. https://doi.org/nobascholar.com

Mochon, D., Norton, M. I., \& Ariely, D. (20II). Who benefits from religion? Social Indicators Research, I0I(I), I-I5. https://doi.org/I0.1007/s II205-0I0-9637-0 
Ndayambaje, E., Pierewan, A. C., Nizeyumukiza, E., Nkundimana, B., \& Ayriza, Y. (2020). Marital status and subjective well-being: Does education level take into account? Cakrawala Pendidikan, 39(I), I20-132. https://doi.org/I0.2I83 I/cp.v39il.29620

Ngamaba, K. H., Panagioti, M., \& Armitage, C. J. (2017). How strongly related are health status and subjective well-being ? Systematic review and meta-analysis. European Journal of Public Health, 27(5), I-7. https://doi.org/I 0.1093/eurpub/ckx08 I

Nizeyumukiza, E., Cilik Pierewan, A., Ndayambaje, E., \& Ayriza, Y. (2020). Trust and wellbeing: Evidence from Indonesia. Asian Social Work and Policy Review, 14(3), I48-157. https://doi.org/ I0.1 I I I/aswp. 12205

Nizeyumukiza, E., Pierewan, A. C., Ndayambaje, E., \& Ayriza, Y. (202I). Social capital and mental health among older adults in Indonesia: A Multilevel Approach. Journal of Population and Social Studies, 29, I-I4. https://doi.org/I0.25 I33/jpssv292021.00 I

Okulicz-Kozaryn, A. (2010). Religiosity and life satisfaction across nations. Mental Health, Religion and Culture, I3(2), I55-169. https://doi.org/10.1080//367467090327380 I

Pierewan, A. C., \& Veenhoven, R. (2018). Quality of life in provinces in Indonesia as measured with happy life years. Retrieved from EHERO Working paper 2018-4

Ramadhani, R. (2019). Studi kasus di Ribat Riba Tazkiyat al-Nafs Tarekat Qadiriyah wa Naqsyabandiyah Bengkulu Selatan. Conciencia, 32-39.

Rammstedt, B., \& John, O. P. (2007). Measuring personality in one minute or less: A 10-item short version of the Big Five Inventory in English and German. Journal of Research in Personality, 4I, 203-2 I2. https://doi.org/I0.1016/j.jrp.2006.02.00 I

Ryan, R. M., \& Deci, E. L. (200I). On happiness and human potential : A review of research on hedonic and eudaimonic well-being. Annual Review of Psychology, 52, I4I-166.

Strauss, J., Witoelar, F., \& Sikoki, B. (2016). User's Guide for the Indonesia Family Life Survey, Wave 5 (Vol. 2). Retrieved from https://www.rand.org/pubs/working_papers.

Wahidin, W. (2017). Spiritualitas dan happiness pada remaja akhir serta. Journal of Innovatife Counseling: Theory, Practice \& Research, I, 57-66.

Zuckerman, P. (2005). Atheism: Contemporary rates and patterns. In M. Martin (Ed.), The Cambridge companion to atheism (pp. 47-67). Cambridge, UK: Cambridge University Press. 